\title{
$\overline{\overline{\underline{\underline{\underline{\mu B}}}}}$ \\ RETORIKA: Jurnal Ilmu Bahasa \\ Vol. 7, No. 2 October 2021, Page 106-114 \\ P-ISSN: 2406-9019 \\ E-ISSN: 2443-0668 \\ Available Online at https://ejournal.warmadewa.ac.id/index.php/jret \\ Flora Ecolexicon and Procedural Eco-Text of Processing Bali Local Culinary
}

\author{
Mirsa Umiyati*, Agus Dharma Yoga Pratama \\ Universitas Warmadewa, Denpasar, Bali-Indonesia \\ *mirsa.umiyati@warmadewa.ac.id, agusdarmayoga85@yahoo.com
}

\author{
How to cite (in APA style): \\ Umiyati, M. \& Pratama, A. D. Y. (2021). Flora Ecolexicon and Procedural Eco-Text of Processing Bali Local Culinary. \\ Retorika: Jurnal Ilmu Bahasa, 7(2), 106-114. doi: https://doi.org/10.22225/jr.7.2.3955.106-114
}

\begin{abstract}
Ecolinguistics is also related to the dimensions of the linguistic social environment. Language only lives in the human brain and in its social use by members of the language community. In this regard, changes in the linguistic and cultural environment, in addition to changes in the physical environment, clearly also change the richness of language cognitively and practically in social-verbal interactions. The aims of this study was to determine the lingual form of the Balinese eco-collection of flora and fauna in the dynamics of food culture, the structure of the procedural ecotext of flora-based local food processing in Balinese verbal recordings and to find out the social religious meaning of native food supporting ecotourism in the tourism industry. This research is descriptive qualitative in accordance with the nature of the symptoms and the objectives to be achieved. The data of this research were obtained through field work. Structured in-depth interviews, observations, and recordings are the mainstay of this research. Interviews were conducted in the context of applying the method of personal experience, namely the method (excavation) of personal experience. The results show that the value of the data in the form of verbal (treasury of the lexicon and terms as well as the text of procedures for processing and preserving local traditional foods based on the environment, then meaning becomes the focus of data analysis work. Language stores experience, knowledge, processes and products of human adaptation as ecological creatures In its interrelationship with its environment, the Balinese language embodies culture, marking the unique, culturallingual power of its people for centuries.
\end{abstract}

Keyword: Balinese, Ecolinguistics, Ecotext of flora

\section{INTRODUCTION}

Balinese language, is a multidimensional phenomenon, in the space of life and the passage of time. As a local language (vernacular), Balinese is multifunctional in the lives of its inheritors. Functions of designation, expression, and representation (Taylor in Gibbon, 2004) function of social glue, markers of ethnic identity (Barker, 2004), language is a verbal symbolic system full of meaning. Language stores experiences, knowledge, processes and products of human adaptation as ecological creatures. In its interconnectedness with its environment, the Balinese language embodies culture, marking the uniqueness, cultural-lingual power of its people for centuries. Native food is evidence of ecological adaptation that accumulates in the dimensions of space and time, reflected in the vocabulary of plant names and their parts.

Language is (also) nomenclature (Saussure, 1985) which Verhaar (1980) categorized as nounsand verbs. Affirmed by Cassirer (1987), words, originally were concrete words. The concrete words are externally referential semantically referring to reality (Verhaar, 2006). Epistemologically, knowledge and experience are also based on sensory activity and 
interaction. Knowledge that produces experience, or vice versa, can be elaborated. The sense of sight listens, knows, and understands the existence of surrounding entities with green leaves, with variations in shape and size. The sense of hearing perceives the rustling of leaves and the sound of birds, the nose perceives the aroma of orange leaves and roses, the tongue perceives the bitter, sweet, sour, and fruity tastes. Linguistically, the sensory perception is encoded and categorized as a qualitative adjective.

Cassirer emphasized that the motivation for managing these entities is because humans have interests. The names of plants and their parts are used as food ingredients, as well as organizing processing procedures with their cultural meanings. The richness and uniqueness of names in local languages (vernacular) is a representation of the interaction, interrelation, and interdependence of society with the diversity in its environment (Fill and Mühlhäusler, 2001), including the diversity of plants. The ecolinguistic perspective reveals the correlation between language variety (language variety), biodiversity (biodiversity), and multicultural (cultural diversity). Linguistically, the difference in lingual signs is arbitrariness so that it distinguishes it from other languages.

In the perspective of ecology, environmental language (ecological linguistics) is based on environmental parameters (environment), diversity (diversity), and parameters of the interrelation, interaction, and interdependence of language with the environment. In addition, the ethnobotany, ethnocultural, and ethnodemographic dimensions are a source of linguistic variants and the richness ofthe ecolexicon and ecotext. The richness and complexity of the Ke-biu-an eco-collection which represents the -banana worldll as a source of food and the community's economy in utilizing bananas (with its varieties and parts: leaves, stems, leaves, flowers, and fruit in Balinese), is multifunctional. Biu -banana and ke-biu-an. The symbolic function of bananas is a rich of meaning in traditional rituals Hindu religion (Yulita, 2020). The dueness of -lontar is spoken in Sabua language (Korroh, 2017), the ke-bataran -corn in Tetun, Timor (Nahak, 2018), and Kemandowe's -sago in Irrires language, West Papua (Syufi, 2019), are examples.

In the course of time, language changes correlate with cultural changes. The culture of cultivation and plantations has changed so that terms and grammar have also developed (Halliday, 2001). Such a change becomes a challenge for applied linguistics in -manipulated language. The-regulatory function controls the behavior of the speaker, to manipulate people in the social and natural environment (Haliday, 1979).

The change in linguistic ecology from monolingual to bilingual-multilingual has a major impact on language life (Haugen, 1992, 2001). Language that is alive, exists in the mind, and is used when communicating. Language life is also determined by social status, intimacy, autonomy, variety, ecological typology, political support, institutions, regulations, standards, orthography. The ability to write Balinese and Latin lontar continuously between generations ensures the preservation of the language.

Before formulating a theoretical framework for ecolinguistics, the concept of the relationship between humans (and society) and the environment should begin with an understanding and awareness that -humans are ecological creatures. Thus, humans (and of course certain language communities) have a reciprocal, integral, and relational relationship with the environment (environment) both on a wide scale (macrocosm, universe, great world) and in which there is a humanecology with its culture on a large scale. Small (microcosm, small universe, little world). This concept is intended that humans are an inseparable part and as a creation that cannot be separated from their life in the deepest and widest sense of the world by listening to everything around them. Humans live and move on a certain space (soil or land), atmosphere, even an environment that has certain spiritual and spiritual dimensions (Keraf, 2014). Thus, understanding the concepts and theories of ecolinguistics (ecolinguistics) initiates this conceptual-theoretical exposure.

Definitively, Ecolinguistics in linguistics, an emphasis-reflectiong the notion of ecology in biological studies- in which the interacting between language and cultural environment is seen as central; also called the ecology of language, ecolinguistics, and sometimes green linguistics, an ecolinguistics approach highlights the value of linguistics diversity in the world, the importance of individual and community linguistics, and the role of language attitudes, lsnguage awareness, language variety, and language change in fostering a culture of communicative peace (Crystal, 2008). 
Ecolinguistics studies the interrelationships between language and the environment (Mbete et al., 2020). This relationship is clearly illustrated in the lexicon (Haugen, 1972) as also described in detail by Sapir below. It is the vocabulary of a language that most clearly reflects the physical and social environmentof its speaker. The complete vocabulary of a language may indeed be looked upon as complex inventory of all the idea, interests, an occupations that take up the attention of the community, and were such a complete thesaurus of language of a given tribe at our disposal, we might to a large extentinfer the character of the physical environment and the characteristics of the culture of the people making use of it (Sapir, 2001).

Dialectical ecolinguistics, which was developed by Bang and Døør, becomes the theoretical basis for dissecting linguistic units in the form of words, terms, sentences, discourses, and texts as social practice. In a dialectical ecolinguistic perspective, language as a social practice has three dimensions: ideological, sociological, and biological (Bang and Døør, 2000). The ideological dimension implies that in social practice, cognitively there is a relationship between individuals and a collective mentality. This includes the treasures of lexicon knowledge and expressions, texts and discourses, supernatural systems (ideology) and physical (physical) systems materially, both biotic (human, animal, plant) and abiotic (water, soil, stone, and so on). ). So, all ideas and collective ideas are included in the cognition system of the language community and specifically in the speech community, all of them live collectively mentally.

Also added, among the treasures of words, lexicon, or sets of terms (Gaho \& Sari, 2021), for example, many contain the meaning of adicita (ideology). Furthermore, the sociological dimension marks the degree of interrelation between citizens of the language community and between people of speech communities, marking the level of intimate relations and the degree of closeness of the relationship, whether full of love, or otherwise lacking, even not knowing each other until they are mutually hostile. The biological dimension implies the meaning that in life in a certain environment, as ecological beings, in essence humans can only live and live together with everything that exists, both animate such as plants and animals and inanimate ones, while still harmonizing and guaranteeing life and well-being life together (Bang and Døør, 2000). Tridimensional in ecolinguistics also confirms that linguistics, in particular ecolinguistics is the science of life (linguistics as life-science) in a broad sense.

Ecolinguistics is also related to the dimensions of the linguistic social environment. As stated by Haugen (1972), language only lives in the human brain and in its social use by members of the language community. In this regard, changes in the linguistic and cultural environment, in addition to changes in the physical environment, clearly change the richness of language cognitively and practically in social-verbal interactions. The change in the linguistic situation from being monolingual to being bilingual is even now increasingly multilingual and multicultural, with clear implications for changing culture and language. Changes in the physical environment, also change the language, technology, and culture of the community.

Ecolinguistic dialectics opens up linguistic insight as a life-science (D $\varnothing \varnothing \mathrm{r} \& \mathrm{D} \phi \varnothing \mathrm{r}, 2000)$. Thelife of language is a manifestation of its tridimensional social practice: ideological, sociological, and biological (Bang \& Døør, 2000), on the spiritual-religious dimension. The ideological dimensions include: cognition, mentality, ideas. The sociological dimension is related to quality-based interpersonal relationships and levels of intimacy (with family members, society, the state), or also thepractice of intimacy, to those that alienate each other. It is in this sociological dimension that language knit social cohesion. The biological dimension emphasizes humans as ecological creatures. In social practice, humans can only live with the availability of various plants and animals, even with abiotic ones (soil, water, and air). Also, space with transcendental spiritual dimensions, individual and communal awareness, social praxis of language organizes harmonious relations with supernatural powers, as a necessity.

In addition to the eco-collection of biodiversity markers, language provides text and discourse, the use of language tells of ecological knowledge and experience. Stibbe (2015) abstracts in the phrase, the stories we life by, the title of his book Ecolinguistics: Language, Ecology, and the Stories We Life Byll. In the ecosophy stores the teachings of ecological wisdom in textual packaging. The constructed ecotext is evaluated for its 
constructive value set that preserves or vice versa destructive ecotext, on the side of the ambivalent text. The discussion of the traditional ecotext, abstracted in Trihita Karana, especially the text of the Tenganan Pegringsingan Traditional Village, Bali with ecosophy facts dissected (Astawa, 2018).

The aims of this research are to find out the lingual form of the Balinese eco-collection of flora and fauna in the dynamics of food culture, the structure of the procedural eco-text of local Balinese food processing based on flora in Balinese verbal recordings, as well as the social religious meaning of native food supporting ecotourism in the tourism industry.

\section{RESEARCH METHOD}

This research is descriptive qualitative in accordance with the nature of the symptoms and the objectives to be achieved. The data of this research were obtained through field work. Structured in- depth interviews (depth interviews), observations (observations), and recordings are the mainstay of this research. The interview was conducted in the context of the application of the personal experiencemethod, the method (excavation) of personal experience as proposed by Clandinin \& Conely (in Denzin and Lincoln, eds. 2009: 571-578). As a result of a qualitative approach using in-depth interviews, data values are in verbal form (treasury of the lexicon and terms and procedural texts for processing and preserving traditional local food based on the environment, then meaning becomes the focus of data analysis work. Of course, as qualitative data then the method of interpretation of the meaning behind the treasures of the lexicon and texts becomes the basis for the analysis as well.The framework of denotative (literal) meaning and external referential meaning (Verhaar, 2017) helps to dissect and find the meaning behind the verbal data.

\section{RESULT AND DISCUSSION}

\section{Flora Ecolexicons and Eco-texts in Balinese}

Table 1. Flora Ecolexicons and Eco-texts in Balinese

\begin{tabular}{|c|c|c|c|c|c|c|c|c|c|c|}
\hline \multirow[t]{2}{*}{ No } & \multirow[t]{2}{*}{ Lexicon } & \multicolumn{2}{|c|}{ Language } & \multicolumn{2}{|c|}{$\begin{array}{c}\text { Environment } \\
\text { al Category }\end{array}$} & \multicolumn{3}{|c|}{$\begin{array}{c}\text { Grammatical } \\
\text { Category }\end{array}$} & \multicolumn{2}{|c|}{$\begin{array}{c}\text { Grammatical } \\
\text { Form }\end{array}$} \\
\hline & & Indonesian & Greek & $\mathbf{B}$ & $\mathbf{A b}$ & $\mathbf{N}$ & $\mathbf{V}$ & Adj & D & $\mathbf{T}$ \\
\hline 1. & Juuk nipis & Jeruk nipis & & + & - & + & - & - & - & + \\
\hline 2. & $\begin{array}{l}\text { Don } \\
\text { belimbing } \\
\text { wuluh } \\
\end{array}$ & $\begin{array}{l}\text { Daun } \\
\text { belimbing } \\
\text { wuluh }\end{array}$ & & + & - & + & - & - & - & + \\
\hline 3. & $\begin{array}{l}\text { Carang } \\
\text { sere }\end{array}$ & $\begin{array}{l}\text { Batang } \\
\text { sereh }\end{array}$ & & + & - & + & - & - & - & + \\
\hline 4. & gula barak & Gula & & + & - & + & - & - & - & + \\
\hline 5. & Don juuk & Daun jeruk & & + & - & + & - & - & - & + \\
\hline 6. & Don Вiи & Daun & & + & - & + & - & - & - & + \\
\hline 7. & $\begin{array}{l}\text { Bungkul } \\
\text { Bawang }\end{array}$ & $\begin{array}{l}\text { Bawang } \\
\text { merah }\end{array}$ & & + & - & + & - & - & - & + \\
\hline 8. & Bungkul & Bawang & & + & - & + & - & - & - & + \\
\hline 9. & $\begin{array}{l}\text { Tabia } \\
\text { Barak }\end{array}$ & Cabai & & + & - & + & - & - & - & + \\
\hline 10. & Kunyit & Kunyit & & + & - & + & - & - & - & + \\
\hline 11. & Cekuh & Kencur & & + & - & + & - & - & - & + \\
\hline 12. & jaé & Jahe & & + & - & + & - & - & - & + \\
\hline 13. & Isen & Terasi & & - & + & + & - & - & - & + \\
\hline 14. & Uyah & Garam & & - & + & + & - & - & - & + \\
\hline 15. & Mica & Merica & & - & + & + & - & - & - & + \\
\hline 16. & Ketubah & Ketumbar & & - & + & + & - & - & - & + \\
\hline 17. & $\begin{array}{l}\text { Sere } \\
\text { Matunu }\end{array}$ & Terasi & & - & + & + & - & - & - & + \\
\hline 18. & $\begin{array}{l}\text { Ukud } \\
\text { siap }\end{array}$ & $\begin{array}{l}\text { Ayam } \\
\text { kampung }\end{array}$ & & + & - & + & - & - & - & + \\
\hline
\end{tabular}




\begin{tabular}{|l|l|l|l|l|l|l|l|l|l|l|}
\hline & Kampung & & & & & & & & & \\
\hline 19. & Yeh & Air & & - & + & + & - & - & - & + \\
\hline $\begin{array}{l}\text { Lengis } \\
\text { Goreng }\end{array}$ & Minyak & & - & + & + & - & - & - & + \\
\hline
\end{tabular}

Procedural Ecotext Structure of Flora-Based Local Balinese Food Processing in Balinese Verbal Recordings

\section{1) Material:}

\section{1 chicken}

$50 \mathrm{ml}$ lime juice

$50 \mathrm{~g}$ star fruit leaves, boiled until soft, drained, roughly chopped Salt2 lemongrass stalks, take the white part

$25 \mathrm{~g}$ brown sugar Citrus leaves to taste

Banana leaves as neededCooking oil for frying

Puree:

10 red onions

6 cloves of garlic 12 curly red chilies

$2 \mathrm{~cm}$ roasted turmeric $2 \mathrm{~cm}$ kencur

$2 \mathrm{~cm}$ ginger, grated

$2 \mathrm{~cm}$ galangal, grated

2 tsp grilled shrimp paste 1 tsp coriander

2 tsp salt

1 tsp pepper granules

\section{2) How to Cook Betutu Chicken}

Coat the free-range chicken with lime juice and salt. Leave it for about 15 minutes in the refrigerator. Heat oil in a frying pan, saute ground spices, lemongrass and brown sugar slices until fragrant. Remove and set aside. Seasonings that have been cooked are divided into 2 parts. One part of the seasoning mix evenly with the chopped starfruit leaves and lime leaves. One part of the other seasoning spread over the entire surface of the chicken. Prick with a fork and knead so that the spices absorb into the chicken meat. Put the star fruit leaves into the chicken stomach until solid. Wrap in banana leaves and steam for 1 hours, remove and set aside. Bake the steamed chicken in the hot oven while basting the remaining cooking spices until the chicken is brown and serve the betutu chicken.

Based on the verbal data that we obtained from the informants and verified by a number of verbal recordings, the following is the structure of the procedural eco-text of processing native Balinese food based on flora in Balinese verbal recordings as follows:

kuliner Khas N-placeRel-banyak

sané akéh

madaging basa

$=$ Kuliner khas Bali yang kaya akan bumbu'
2. Betutu artine proses ngolah
Betutu artinya V-proses V-mengolah N-daging

$=$ Betutu artinya proses mengolah daging ${ }^{6}$

3. Pidan, betutu kaolahang tekén Bébék
Awalnya N-betutu PAS-masak CONJ-dengan bebek

=Awalnya betutu dimasak dengan bebek ${ }^{6}$

4. Nanging mangkin sampun bisa

CONJ-namun saat ini

bisa V-menggunakan

bébéklan siap bebek CONJ-dan ayam =Namun sekarang sudah bisa menggunakan bebek dan ayam "

5. Sejarahé nyatet, pidan ngerateng betutu nganggén carakuno Sejarah N-catat awalnya V-memasak betutu V-guna carakuno tur dagingina basa tabia lan base genep khas

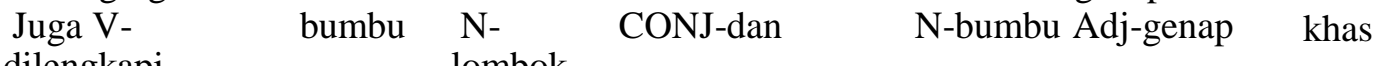
dilengkapi lombok

$=$ Sejarah mencatat, memasak ayam betutu awalnya dilakukan secara kuno dan dilengkapi dengan bumbu cabai serta base genap khas'

$\begin{array}{lll}\text { 6. Caran ngerateng } & \text { siap } & \text { utuh } \\ \text { Caranya V-tutu, siap } & \text { Adj-utuh } \\ \text { kakaputin aji } & \text { N-daging pengolah pinang. } & \\ \text { PAS-lapis dengan } & \text { daun pisang } & \\ \text { =Pengolahan ayam betutu yakni ayam utuh dilapisi daun pinang، } & \end{array}$




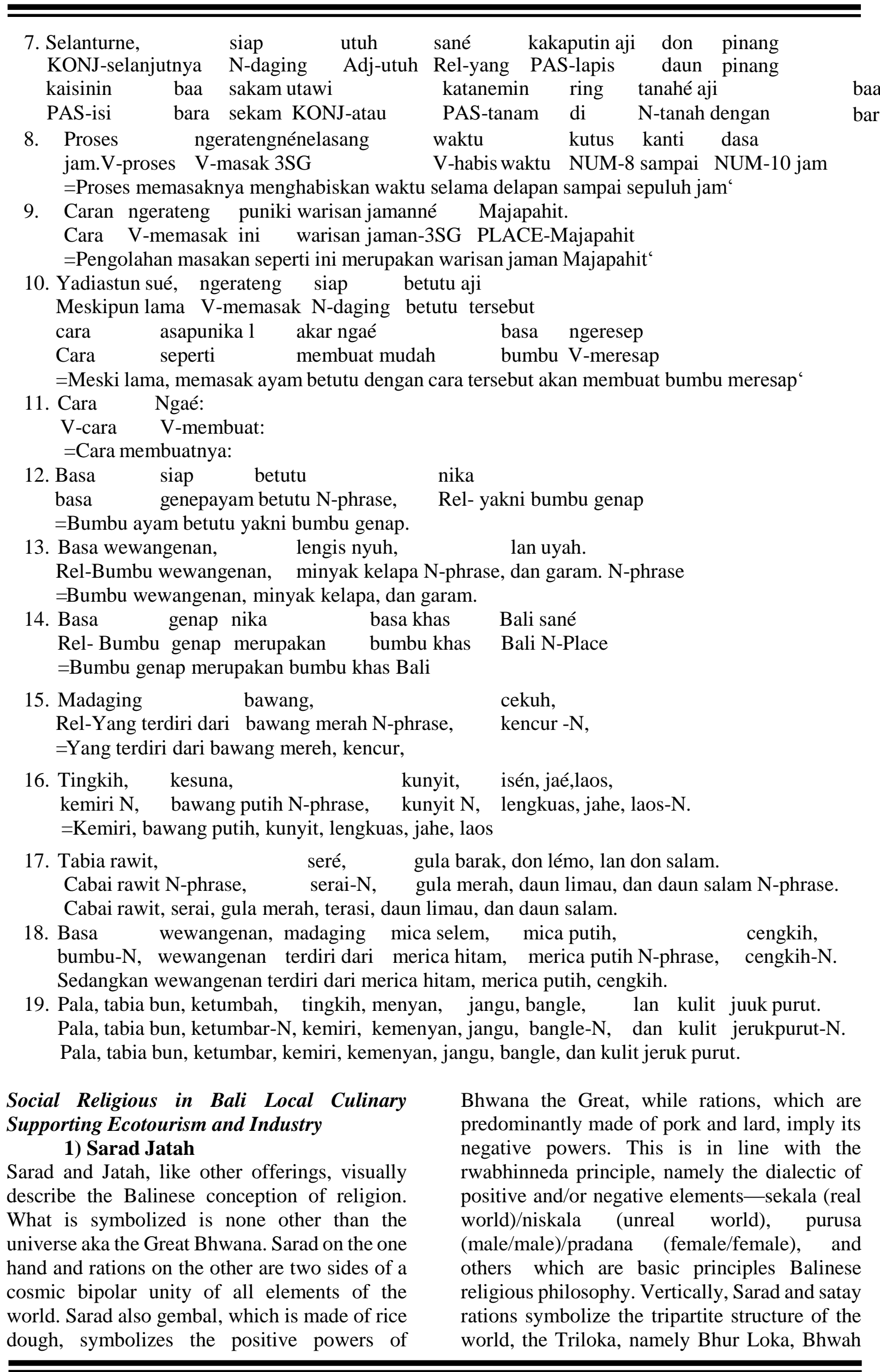


Loka, Swah Loka. The Sarad on the left is colorful and made of shaped, fried rice flour snacks that symbolize the positive elements of Rwabhinneda. The ration on the right, darker in

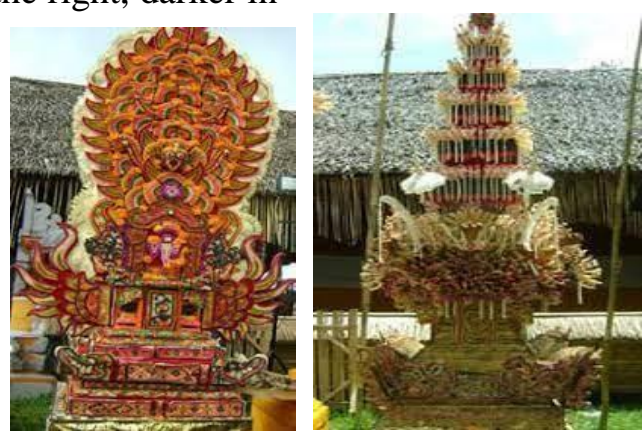

Figure 1. Sarad and Jatah

\section{Banten: Symbol and Meaning}

a. Sarad

a) The tortoise, known in Bali as Bedawang Nala, symbolizes the earth's foundation, namely magma fire (Putra $\mathrm{tt}: 24)$, as the element of fire. In mythology, as described in Adiparwa (Widyatmanta 1958:44), he is considered as "the incarnation of Lord Vishnu".

b) Dragons symbolize the basic elements of the earth. "Dragon Anantaboga symbolizes the element of the earth's crust and Naga Basuki the element of water and ocean" (Putra tt:24). Thereis a third dragon, the Taksaka dragon, which represents the element of air, but it is not usually given the form of Sarad and Ration offerings. The three dragons are discussed on several occasions in Adiparwa's version of the story of Mandara Giri's play (Widyatmanta 1958). According to Putra (Putra tt: 24), "the three dragons are the result of the meeting of the three Trimurti gods Brahma, Vishnu and Shiva with each representing land, water and air".

In the middle (Bwah Loka), it can be seen humans and the elements of the living world: plants, animals and humans. In most of the Sarad made, there are only figures of Bhoma and Garuda as representatives of the intermediate world, but there are also Sarad which contain human figures. Often there are also coral decorations that symbolize natural creatures - coral asti (elephant), coral wurung, coral bentulu, coral sae, and others). Garuda symbolizes a flying creature. As narrated at length in Adiparwa (Widyatmanta 1958:48-63). In color, and made of meat, symbolizes the negative element of rwabhinneda.

short, Garuda, in his search for the holy water of amerta, must subdue and kill various terrible creatures - especially snakes, elephants and turtles - before reaching his destination and obtaining the amerta. He was then asked by Vishnu to be his vehicle. It symbolizes that eternal life can only be achieved if we are able to overcome worldly desires. The topmost part of the skid is the place where the gods (Swah Loka) live with their various emblematic figures. Sometimes there are figures that symbolize the Trinity, namely Brahma, Vishnu and Shiva, or single figures that symbolize Indra (king of the gods) or Sang Hyang Tunggal aka Sang Hyang Widhi.

\section{b. Jatah}

The general conception of satay rations is no different from that of sarad, which both symbolize the contents of the world. Many of the symbols given form are the same as Sarad, namely Bedawang Nala, Nagas, Garuda, Bhoma. But his trademark is the weapons of the gods ruling the cardinal directions, which are made from various processed meats and fats. Pork is the main ingredient, but it can also be made from the meat of other sacred animals (except beef) namely: buffalo, duck, goat or turtle. So, like Sarad, Jatah gives a symbolic form to traditional HinduBalinese pantheism.

\section{1) Betutu Chicken}




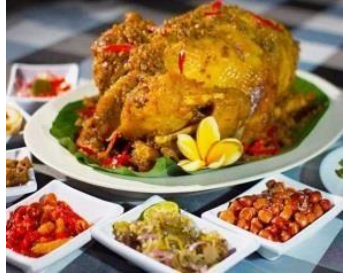

Figure 2. Betutu Chicken

Initially, betutu functioned as inward diplomacy, namely as a means of offering to Ida Hyang Widhi Wasa through the Dewa Yadnya ceremony. However, it is further dedicated to the completeness of other Yadnya such as Pitra Yadnya, Blind Yadnya, Rsi Yadnya, and Manusa Yadnya, so it is not surprising that betutu has a religious and social function. In organizing the ceremony, there are several ceremonies that must be accompanied by offerings with betutu, both duck betutu and chicken betutu, such as during the otonan ceremony (classified as the manusa yadnya ceremony), banyu pinaruh, tumpek uduh, tumpek landep, ngasti ceremony and if someone takes a vow (mesaudan), in genahbawa offerings, in pranic offerings. The type of betutu served by duck betutu. The positioning and selection of the duck betutu in the religious ceremonial equipment mentioned above can be understood because the duck animal is a symbol of a sacred animal. Sacred animals are interpreted as animals that are able to distinguish between good and bad, between valuable and unworthy, between worthy and unworthy, and worthy and inappropriate. In everyday reality when eating, ducks never fight for food. Especially when they peck each other. Duck animals can choose and sort out which food is appropriate to eat, so ducks are often interpreted as animal symbols of wisdom. The food dishes of holy people (Brahmins) at the time of holding religious ceremonies are generally betutu duck.

\section{2) Lak-Lak}

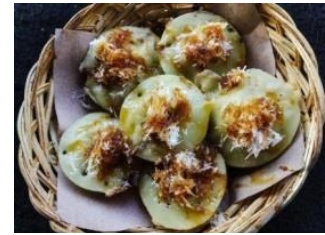

Figure 3. Lak-Lak

Every food has a name and philosophy in it, a food can be used as a regional identity because it has a history of how the food existed. One example is Lak- lak which is a typical food of
Bali or Ubud because lak-lak is one of the foods used for yadnya (banten) and piodalan ceremonies as a thanksgiving to Hyang Widhi by the Balinese people.

\section{3) Lawar Bali}

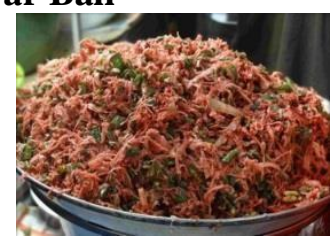

Figure 4. Lawar Bali

Lawar is a typical Balinese dish which is generally made from grated coconut mixed with minced meat (pork or chicken or turtle), Balinese spices, and of course half-cooked blood. Lawar is a dish that must be present in every traditional Balinese party activity. Because without lawar, the food served is incomplete. Besides being delicious, lawar as a traditional Balinese food turns out to have its own philosophy. Basically, lawar consists of several ingredients. First is meat. The second is a spice consisting of fruits, leaves, and tubers (nutmeg chunks and nutmeg hanging). If it is associated with Catur Dala (four gods according to the four cardinal directions), then several materials can represent it. First, the white coconut is a symbolof Dewa Iswara, the ruler of the east. Second, red blood is a symbol of Lord Brahma who is the ruler of the south. Furthermore, the yellow spices are a symbol of Lord Mahadewa, the ruler of the west, while the black color, such as shrimp paste, is a symbol of Lord Vishnu, the ruler of the north.

Lawar means harmony and balance. This can be seen from the ingredients that make it, namely:

- grated coconut (white, symbol of Lord Iswara in the east)

- blood (red, symbol of Lord Brahma in the south)

- $\quad$ spices (yellow, a symbol of God Mahadeva in the west) and

- terasi (black, symbol of Lord Vishnu in the north)

\section{4) Satay Lilit}




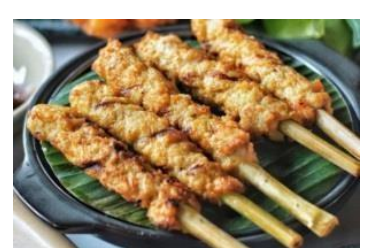

Figure 5. Satay Lilit

Talking about the history of satay lilit, it turns out that this satay has been around for a long time in Bali and is always served during traditional or religious ceremonies. This is not without reason because there is a philosophy behind it. Investigate a calibaration, it turns out that this satay wrap symbolizes a unifying sign for the Balinese people. Sate lilit whose flesh is wrapped around a lemongrass stalk symbolizes the Balinese people, while the lemongrass stalk is the unifier. Sate Lilit is a symbol of Lord Brahma's weapon in the form of a mace, which is a convex bat-like weapon with a straight base as the handle. Sate lilit is not only enjoyed, Hindus also offer it in religious events such as the caru ceremony, this ceremony aims to honor the gods and the number of satays that must be served must be odd.

\section{CONCLUSION}

The results of the activity went according to the target and showed that most of the younger generation did not know traditional Balinese culinary. So in this study, researchers had the opportunity to provide solutions in the form of Language Documentation to provide knowledge in the form of culinary names, tools and materials and how to serve them. Basically this activity seeks to revitalize Balinese culture in the form of traditional culinary to support ecotourism and industry.

\section{REFERENCES}

Astawa, I. G. (2019). Ekosofi Tri Hita Karana Dalam Awig-Awig Desa Adat Tenganan Pegringsingan: Analisis Ekolinguistik Kristis". (disertasi). Program Doktor Ilmu Linguistik, Universitas Udayana.

Barker, C. (2004). Cultural Studies. Teori \& Praktik. Diterjemahkan oleh Nurhadi. Pustaka Pelajar. Yogyakarta.

D., C., F., J., \& Conely, M. (2009). Metode Pengalaman Pribadi" dalam Denzin, Norman K dan Yvonna S. Lincoln 2009. Handbook of Qualitative Research. Diterjemahkan oleh Daryatno dkk. Pustaka Pelajar, Yogyakarta.

Gaho, R., \& Sari, R. P. (2021). The Existence of Fauna Lexicon in the Elefu Song Lyrics Composed by Hikayat Manao: Ecolinguistics
Study. International Seminar on Social Science, Humanities, and Education (ISSHE), 1(1).

Halliday. M. A. K. (2001). New Ways Of Meaning The Challenge to Applied Linguistics. dalam Alwin Fill, Peter Mühlhäusler (Eds.) 2001. The Ecolinguisics Reader: Language, Ecology and Environment. Continuum. London \& New York.

Keraf, S. (2014). Filsafat Lingkungan Hidup. Alam sebagai Sebuah Sistem Kehidupan. Kanisius. Yogyakarta.

Mbete, A. M., Koroh, L., Setiawan, I. N., \& Sari, R. P. (2020). Ekolinguistik: Analisis Kasus dan Penerapan Prinsip Dasar. Jayapangus Press Books.

Sapir, E. (2001). 'Language and Environment' dalam Alwin Fill, Peter Mühlhäusler (Eds.) 2001. The Ecolinguisics Reader: Language, Ecology and Environment. Continuum. London \& New York.

Syufi, Y. (2019). Khazanah Leksikon Kesaguan Guyub Tutur Masyarakat Irire Papua Barat: Perspektif Ekolinguistik". (disertasi). Program Doktor Ilmu Linguistik. Universitas Udayana. Denpasar.

Verhaar J.W.V. (1880). Teori Linguistik dan Bahasa Indonesia. Kanisius. Yogyakarta. Fill, Alwin, \& Mühlhäusler, P. (2001). The Ecolinguistics Reader: Language, Ecology and Environment. Continuum. London and New York.

Verhaar J. W.V. (2006). Umum, Asas-asas Linguistik. Gadjah Mada Univerity Press. Yogyakarta. 